マットに拈けるZnSの熱力学的研究をそれぞれ第 1 報, 第 2 報で報告したが，この第 3 報では，以上の研究をも とにして，実際のマットにより近い，複雑な形をしたマ ッ不，すなわち $\mathrm{Cu}_{2} \mathrm{~S}-\mathrm{ZnS}-\mathrm{FeS}$ 三元系のマットに関し ての研究結果を報告する。いろいろの種類の三元系マッ トについて, $\mathrm{ZnS}$ 蒸気圧を測定し，その結果から三元 系マットにおけるZnSの等活量曲線をひいた。

\section{2. 実験方法}

$\mathrm{Cu}_{2} \mathrm{~S}-\mathrm{ZnS}-\mathrm{FeS}$ 系マット中の $\mathrm{ZnS}$ の蒸気圧測定方法 壮第 1 報, 第 2 報と同様である。この実験で使われたマ ットは $\mathrm{Cu}_{2} \mathrm{~S}$ と $\mathrm{FeS}$ との比が $2.7: 1,1: 1,1: 3$ の $\mathrm{Cu}_{2} \mathrm{~S}$ - $\mathrm{FeS}$ 系マットに $\mathrm{ZnS}$ を添加したもので, $\mathrm{Cu}_{2} \mathrm{~S}$ と $\mathrm{FeS}$ 第 1 報，第 2 報で使用したと同じものを用い，実際は $\mathrm{Cu}_{2.12} \mathrm{~S}, \mathrm{FeS}_{0.96}$ の形をしている。露点測定のための試

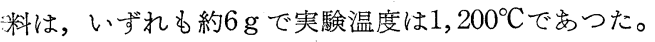

\section{3. 実験結果および考察}

三元系マットの各種の試料について $\mathrm{ZnS}$ 露点を測定 し，それから活量を計算した結果を第 6 図に示す。 $\mathrm{Cu}_{2} \mathrm{~S}$ と $\mathrm{FeS}$ と比 $\left(\mathrm{Cu}_{2} \mathrm{~S} / \mathrm{FeS}\right)$ が大きくなるにしたがい $\mathrm{ZnS}$ の活量も大きくなつているが，このことは $\mathrm{Cu}_{2} \mathrm{~S}-\mathrm{ZnS}$
系, $\mathrm{FeS}-\mathrm{ZnS}$ 系についての $\mathrm{ZnS}$ の活量曲線からも容易 に推定できることである。これらの活量曲線と第 6 図か ら $\mathrm{Cu}_{2} \mathrm{~S}-\mathrm{ZnS}-\mathrm{FeS}$ 系マットに打ける $\mathrm{ZnS}$ の等活量曲線 を求めることができる。その結果を第 7 四に示した。

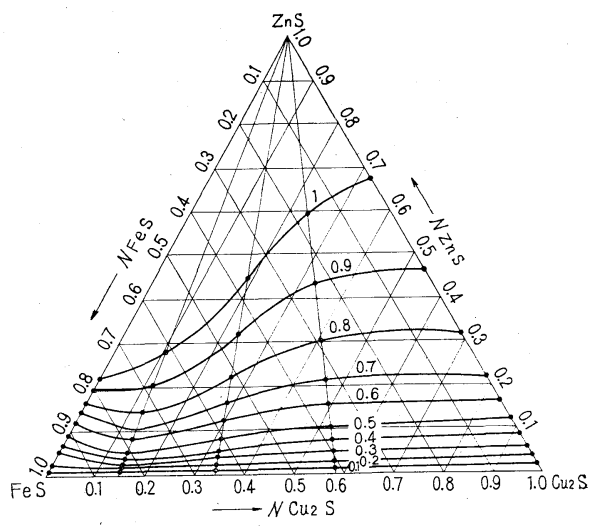

第 7 図 $\mathrm{Cu}_{2} \mathrm{~S}-\mathrm{ZnS}-\mathrm{FeS}$ 系マットル晾子る $\mathrm{ZnS}$ 等活量曲線 $\left(1,200^{\circ} \mathrm{C}\right)$

\title{
3404 乾式錫製錬の基礎研究
}

溶融 $\mathrm{SnO}-\mathrm{SiO}_{2}$ 系に関する熱力学的研究

$\begin{array}{cccc}\text { 京都大学工学部助教授・工博 } & \text { ○幸 塚 善 } & \text { 作(正会員) } \\ \text { 京都大学工学部大学院学生 } & \text { オロアン・シアハアン* } \\ \text { 京都大学工学部教授・工博 } & \text { 森 山 } & \text { 徐 一 郎(正会員) }\end{array}$

\section{1. 緒言}

乾式錫製鍊においては，とくに溶融スラグ中の成分の 挙動が重要であるにもかかわらず，この方面の研究はき わめて少ない。筆者らは $\mathrm{SnO}$ を含む溶融珪酸塩の熱力 学的性質を明らかにする目的から，むずつぎのような研 究を行なつた。固態電解質を用いた起電力測定法によ り, 溶融 $\mathrm{SnO}-\mathrm{SiO}_{2}$ 系中の $\mathrm{SnO}$ の活量を決定し, その実 験結果を用いて各種熱力学的数值を計算した。

\section{2. 実験 方 法}

固態電解質としては $\mathrm{CaO}$ で安定化したジルコニアを 用い,つぎのような電池を構成し，その起電力を測定し た。

$$
\mathrm{Sn}, \mathrm{SnO}(l) / \mathrm{ZrO}_{2}(\mathrm{CaO}) / \mathrm{Sn}, \mathrm{SnO}-\mathrm{SiO}_{2}(l)
$$

この場合の電極反応はつぎのように示される。

除極では $\mathrm{SnO}+2 \mathrm{e}^{-} \rightarrow \mathrm{Sn}+\mathrm{O}^{2-}$

陽極では $\mathrm{Sn}+\mathrm{O}^{2-} \rightarrow \mathrm{SnO}$ (in silicate) $+2 \mathrm{e}^{-}$

合計 $\mathrm{SnO} \rightarrow \mathrm{SnO}$ (in Silicate)

すなわち，この電池の起電力 $E$ を測定すれば，溶融 $\mathrm{SnO}-\mathrm{SiO}_{2}$ 系中の $\mathrm{SnO}$ の活量を(1)式にしたがつて計算 することができる。

$$
-2 E F=R T \ln a_{\mathrm{SnO}}
$$

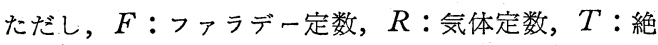

\footnotetext{
* インドネシフ留学生
}

対温度, $a_{\mathrm{SnO}}: \mathrm{SnO}$ の活量

実験装置の概略は第 1 図に示す。固態電解質として作

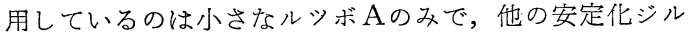
コニアからなる大きなルツボ $\mathrm{B}$ および管 $\mathrm{C} は$ は, 単に耐火 物として用いている。またりード線 $\mathrm{D} と し て は ， 700{ }^{\circ} \mathrm{C}$ で 1 週間空気中で加熱することによつて緻密な酸化膜を 作つたステンレス鋼線を用いた。このようなステンレス 鋼線を用いても長時間溶融 $\mathrm{SnO}$ 中に浸漬すれば，かな り酸化されるので，電位差を測定する数秒間だけ浸漬す ることにした。 $\mathrm{SnO}-\mathrm{SiO}_{2}$ 系試料はめらかじめアルゴン ガス雾囲気中で溶融したものを用い, 起電力測定実験も アルゴンガス雾讲気で, $1,050^{\circ} \sim 1,150^{\circ} \mathrm{C}$ の温度範讲で行 なつた。

\section{3. 実験結果および考察}

7 種の組成をるつ $\mathrm{SnO}-\mathrm{SiO}_{2}$ 試料について行なつた起 電力測定結果を第 2 図に示す。 $\mathrm{SnO}$ のモル分率を $N_{\mathrm{SnO}}$ とする時 $N_{\mathrm{SnO}}=0.22,0.36$ の 2 試料は液相と固相の共 存する組成になると考えられ，両者は同じ起電力を示す ことが予想される。この事実は本実験でも認めることが でさた。その他の 5 種の試料はすべて均一液相をなすも のである。以上の実験結果を用い，(1)ょり $\mathrm{SnO}$ の活 量を，また Gibbs-Duhem の式を用いて, $\mathrm{SiO}_{2}$ の活量 $a_{\mathrm{SiO}_{2}}$ を決定することができる。 $1,100^{\circ} \mathrm{C}$ に打る $a_{\mathrm{SnO}}$ および $a_{\mathrm{SiO}_{2}}$ の值を第 3 図に示す。 $\mathrm{SnO}-\mathrm{SiO}_{2}$ 系のよ5 な二元珪酸塩に扎いては，Temkinの表現を用いた場 


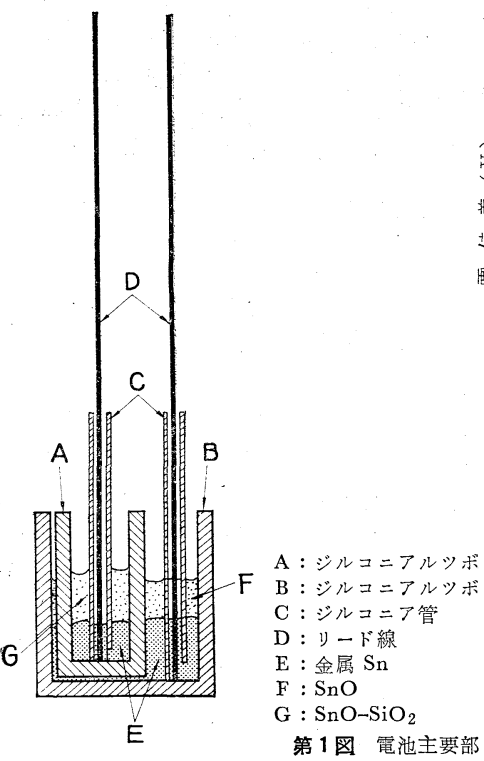

合， $a_{\mathrm{SnO}}=a_{\mathrm{Sn}^{2}+} \times a_{\mathrm{O}^{2-}}=a_{\mathrm{O}^{2}-}$ なる関係があるから $\mathrm{O}^{2-}$ なるイオンの活量を決定したことになる。第 3 図中に D. M. Chizhikov らが $\mathrm{Sn}, \mathrm{SnO} / \mathrm{Al}_{2} \mathrm{O}_{3} / \mathrm{Sn}, \mathrm{SnO}-\mathrm{SiO}_{2}$ なる電池を用いて，最近決定した $a_{\mathrm{SnO}}$ の值を併記して いるが，かなり異なつた結果を示している。すでに発表 されている状態図に基いて考察すれば当然态研究結果の 方が正しいと考觉られるが，さらに他の方面から検討す べきで岁ろう。本研究結果によれば， $a_{\mathrm{SnO}}$ は均一液相 範囲では，わずかではあるが Raoult の法則より正の方 に偏倚し, 固相が析出するような低 $\mathrm{SnO}$ 濃度でも, か なり高い活量を示すことが認められる。またさらに各種 熱力学的数值を求めたが, その中で $\Delta F_{\mathrm{mix}} / 4.575 T$ なる 関数を第 4 図に示した。ただし $\Delta F_{\operatorname{mix}}$ は混合の時の自 由エネルギー変化を表わす。この関係はToopと Samis の溶融珪酸塩に関するモデルについて検討するために図 示したものである。図中に示される数本の曲線は彼らが 独特のモデルに基いて計算した值を示し，Kはつぎのよ うな反応の平衡恒数を表わす。

$$
\mathrm{O}^{2-}+\mathrm{O}^{0}=2 \mathrm{O}^{-}
$$

ただし $\mathrm{O}^{2-}, \mathrm{O}^{0}, \mathrm{O}^{-}$はそれぞれ溶融珪酸塩中の結合状 態の異なる 3 種類の酸素イオンを示す。第 4 図に $\mathrm{CaO}$

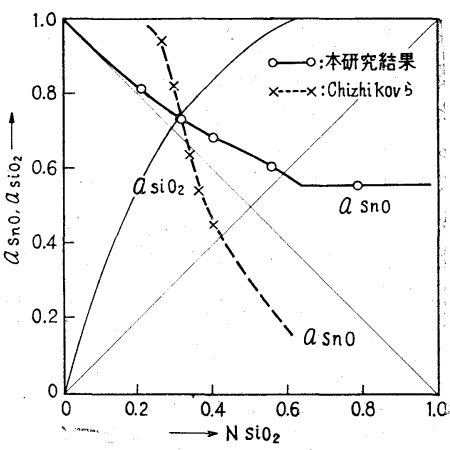

第 3 园 $1,100^{\circ} \mathrm{C}$ 和任る溶融 $\mathrm{SnO}-\mathrm{SiO}_{2}$ 系. 中の $\mathrm{SnO}, \mathrm{SiO}_{2}$ の活量

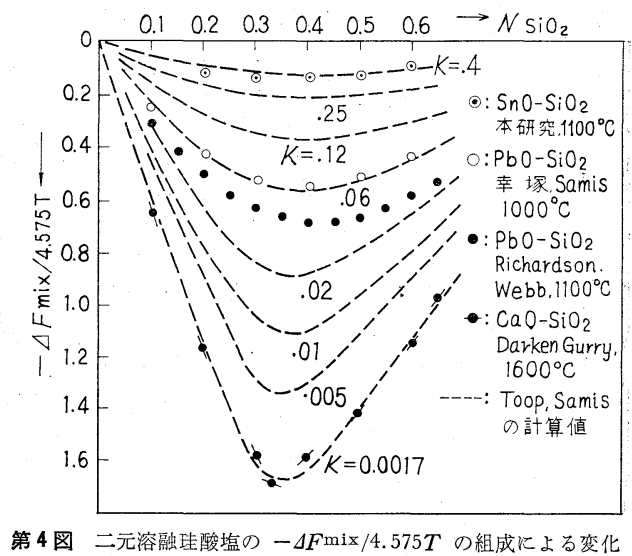

$\mathrm{SiO}_{2}$ 系に関する Darken らの計算值, $\mathrm{PbO}-\mathrm{SiO}_{2}$ 系に 関するRichardson らの実験值および筆者らの 1 人が行なつた起電力測定值からの計算值と $\mathrm{SnO}-\mathrm{SiO}_{2}$ 系に関す る本研究結果を示した。この第 4 図によれば $\mathrm{SnO}-\mathrm{SiO}_{2}$ : 系は $K=0.4, \mathrm{PbO}-\mathrm{SiO}_{2}$ 系では0.06または0.04, $\mathrm{CaO}$ $-\mathrm{SiO}_{2}$ 系では $K=0.0017$ として Toop, Samis のモデ ルにしたがつて計算した值とよく一致することが認めら れる。これらの解釈はさらに今後の研究によつて明らか. にされるであろ5。今後さらに $\mathrm{SnO}-\mathrm{SiO}_{2}$ 系状態図の 確認, $\mathrm{Sn}, \mathrm{SnO}, \mathrm{SnO}_{2}$ 間の平衡関係の確認なぞの問題点 を残しているので, 他の面からも検討するつもりである。

\section{5 亜鉛蒸気の反応性に関する研究（第 3 報）}

—クロームおよび鉄ークローム系ステンレス鋼への亜鉛蒸気の拡散—

$\begin{array}{rrrrr}\text { 東京大学工学部教授・工博 } & \text { 吾 } & \text { 妻 } & \text { 潔(正会員) } \\ \text { 東京大学工学部助教授・工博 } & \text { 後 } & \text { 藤 } & \text { 佐 } & \text { 吉(正会員) } \\ \text { 東京大学工学部大学院学生 } & \text { ○点 } & \text { 裕 } & \text { 慶(准会員) }\end{array}$

\section{1. 緒言}

第 1 報では鉄中に打ける亜鉛蒸気の拡散および炭素を 添加した場合の影響を明らかにし，第 2 報ではニッケル 打よびオーステナイト系ステンレス銅への亚鉛蒸気の拡 散について述べた。
本報では12Cr, 18Cr, 30Crなどの $\mathrm{Fe}-\mathrm{Cr}$ 系ステンレ ス鋼への拡散执よびそれに対する耐食性について報告す る。第 2 報で述べたようにニッケル扰よびそれを含有す るステンレス鋼は亜鉛蒸気により著しく扐かされること がわかつた。クロームは溶融亜鉛によつて幾分扣かされ るが，亚鉛蒸気に対してはほとんど窗食されない。鉄中 